\section{British panel bans use of antidepressant to treat children}

\section{Alison Abbott}

UK regulators have ruled that a topselling antidepressant should not be prescribed to children or adolescents who are suffering from depression.

The drug, paroxetine, is an ineffective treatment for major depression in this age group and could possibly increase suicidal tendencies, the Committee on Safety of Medicines (CSM) said on 10 June.

Paroxetine, a member of the same class of drug as Prozac, is widely used to treat depression and other nervous disorders. It is not licensed for use in children but can be prescribed by doctors on an individual basis - about 8,000 patients aged under 18 have been given the drug in Britain in the past year.

The CSM's ruling followed a review of fresh clinical data on 1,200 children treated with paroxetine for depression, social anxiety and obsessive-compulsive disorder. The information was provided by UK-based drug firm GlaxoSmithKline (GSK), which markets the drug under the name of Seroxat in Britain and as Paxil in the United States.

The data show that the children with depression did not benefit from taking the drug, the CSM said. It added that there was a two to three times higher incidence of "potentially suicidal behaviour" among those treated with the drug compared with those receiving a placebo, although total numbers were too small to be statistically significant.

The CSM did not rule on using paroxetine to treat social anxiety or obsessive-compulsive disorder, for which there was evidence of efficacy.

On 13 June, Senator Charles Schumer (Democrat, New York) called on the US Food and Drug Administration (FDA), to investigate the effects of paroxetine on children and teenagers. The FDA was expected to announce an investigation this week.

Over the past few years, GSK has been under increasing pressure from patients and their supporters, who say that paroxetine increases suicidal tendencies in all age groups. The company says that there is no evidence for this.

David Nutt, a psychopharmacologist at the University of Bristol, UK, says that the CSM ruling has little bearing on the debate about paroxetine's possible side effects in depressed adults. The CSM was concerned that the drug was ineffective in depressed children, so there was no reason to take any risk, he says.

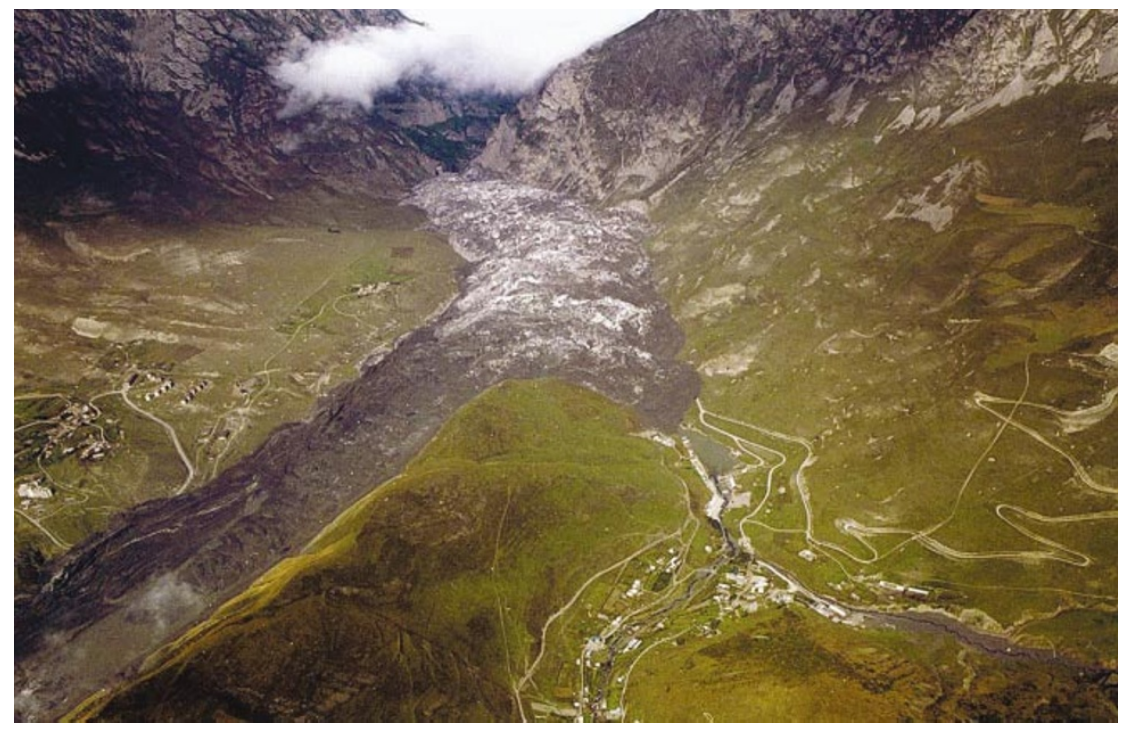

The climate-change debate in Russia is being charged by natural disasters such as this glacier collapse.

\title{
Researchers rattled as Kyoto Protocol hangs in the balance
}

Quirin Schiermeier, Munich

European climate researchers are expressing unease about the objectives of a conference to be held in Moscow this autumn. They fear that sceptics in Russia want to use the meeting to help block ratification of the Kyoto Protocol on Climate Change.

Several scientists, who didn't want to be identified, told Nature that they had considered boycotting the forthcoming World Climate Change Conference (WCCC), after attending a programme committee meeting in Moscow last month.

But the researchers said that they had decided to press on with the conference, in the belief that a boycott would offend the Russians and jeopardize climate negotiations inside and outside Russia.

Ratification of the Kyoto Protocol is currently being debated by the Russian administration and, if it happens, would mean that the international treaty would finally come into force. But the debate is very finely balanced, and some researchers fear that climate-change sceptics in Russia want to use the WCCC meeting to block ratification.

Western researchers privately complain about what they regard as the autocratic behaviour of YuriIzrael, the Russian chairman of the programme committee, at last month's preparatory meeting. It was a "pseudodemocratic exercise, everything was stagemanaged," says one German participant.

Izrael is a vice-chairman of the Intergovernmental Panel on Climate Change (IPCC), and a science adviser to the Russian president, Vladimir Putin, who will open the meeting on 29 September. The 73-year-old former director of the Russian weather service, Izrael is described by his critics as firmly rooted in Soviet scientific traditions. $\mathrm{He}$ is also well-known for his reservations about the Kyoto Protocol.

At least one participant has decided not to attend the WCCC. "The objectives of the meeting have not become clear to me at all," says Ulrich Cubasch, a meteorologist at the Free University in Berlin. "I don't want to let myself be used for purposes which I may not want to support."

"The WCCC would be an occasion to raise important issues," says Hervé Le Treut, director of the Laboratory of Dynamical Meteorology in Paris. "But after all the difficulties in discussing things freely at the preparatory meeting, I have very mixed feelings about this conference." He adds that he has not yet decided whether he will accept an invitation to give a talk at the conference.

But Izrael dismisses the criticism. "It will be a purely scientific meeting," he says. "There will be no political decisions or recommendations.'

The first scientific speaker on the programme, former IPCC chairman Bert Bolin, has said that he will attend the conference, and most of the 37 invited Western keynote speakers are following suit.

"A boycott of Western scientists would only help those who might be interested in steering the climate debate in Russia in a direction that they see fit," says Hartmut Grassl, an atmosphere researcher at the Max Planck Institute for Meteorology in Hamburg.

www.wcec2003.org 